Ind. Health, 1964, 2, 172.

\title{
RAPID METHOD OF QUANTITATIVE MINERALOGICAL ANALYSIS OF THE SILICA MINERALS FROM THE LUNGS OF THE REFRACTORY WORKERS
}

\author{
Hisato Hayashi and Kaoru Oinuma \\ National Institute of Industrial Health, Kizuki-Sumiyoshi, Kawasaki \\ and \\ National Science Laboratory, Toyo University, \\ Haramachi, Bunkyo-ku, Tokyo
}

(Received August 31, 1964)

\begin{abstract}
Accurate knowledge of mineralogical composition of the dust from the lungs should be helpful for understanding pathological changes of pneumoconiosis. The dust from the lungs of refractory workers in silica refractory industry is composed mainly of quartz, tridymite and cristobalite. This paper describes a rapid $X$-ray diffractometer method for quantitative determination of quartz, tridymite and cristobalite in the dust from the lungs. Pure standards of quartz, tridymite and cristobalite were produced and several mixtures of these were prepared. The diffraction patterns of each pure member and of the mixtures were recorded with an $X$-ray diffractometer in the range of 4.5 $\AA-3.3 \AA$ at a slow scanning speed. The diffraction pattern of the dust from the lungs was recorded and compared with the standard patterns mentioned above. The weight percentage of each mineral was calculated on the basis of the intensity ratio of the $3.35 \AA$ quartz peak, the $4.04 \AA$ cristobalite peak and $4.31 \AA$ tridymite peak.
\end{abstract}

The dust in refractory industry containes silica minerals. Silica refractories are, from a mineralogical point of view, composed of tridymite and cristobalite with some residual quart $z$ and small amounts of silicates, other minerals and siliceous glass. The actual amounts of the three silica minerals, namely, quartz, tridymite and cristobalite, have a great infiuence on the thermal properties of such refractories. A silica refractory containing only tridymite would be highly desirable in respect of thermal properties. Since the pioneering work of Fenner in $1913,{ }^{1)}$ the stability relation of silica minerals at high temperature has been modified. ${ }^{2 \sim 6)}$ Recent works in this field suggest that the process of transformation of quartz into cristobalite or tridymite is an indirect one involving an intermediate phase. ${ }^{7,8)}$ Accurate knowledge of the mineralogical composition of silica refractories is therefore important. Pneumoconiosis is the result of continuous inhalation of dust into 


\section{SILICA MINERALS FROM REFRACTORY WORKERS' LUNGS}

the lungs and it depends on the interaction between the man and dust cloud to which he is exposed. The dust in refractory industry contains silica minerals. The individuals working in refractory industry inhale the dusts of silica refractories, such as quartz, tridymite and cristobalite, and consequently are affected with silicosis. A rapid and accurate method of quantitative analysis of silica minerals would be particularly valuable in improving thermal properties of silica refractories, and in investigation of the relationship between exposure to dust and degree of pathological changes of the lungs.

This paper describes rapid X-ray diffraction and infrared absorption methods for determination of the weight percentage of quartz, tridymite and cristobalite in the dust retained in the pneumoconiotic lungs.

\section{METHOD}

\section{Preparation of Standards}

The quartz standard used in this study was acid-washed Ishikawayama quartz from Fukushima Prefecture in Japan. For preparing tridymite, the powder of quart $z$ was heated at $600^{\circ} \mathrm{C}$ and then thrown into a $10 \%$ sodium bicarbonate solution, and the particles were recovered by centrifugal separation. Tridymite was prepared by reacting a mixture of $4 \mathrm{~g}$ of this treated powder of quartz and $1 \mathrm{~g}$ of sodium bicarbonate at $1350^{\circ} \mathrm{C}$ for 10 hours with subsequent slow cooling. No evidence of quartz, glass or cristobalite could be detected in this synthetic tridymite under a petrograpric microscope or by X-ray diffraction analysis.

Cristobalite was prepared by reacting a mixture of $4 \mathrm{~g}$ of the treated quartz, $0.4 \mathrm{~g}$ of alumina and $0.5 \mathrm{~g}$ of sodium bicarbonate at $1000^{\circ} \mathrm{C}$ for 10 hours.

No trace of quartz or or tridymite could be found by X-ray diffraction method.

Particle size of these three minerals was set at 0.1 to $5 \mu$ by hydraulic elutriation, following the size of dust in the lungs studies by Cartwright and Nagelschidt $(1961) .^{9)}$

\section{Preparation of Lung Dust Sample}

Although various methods are available for separetion of the dust from the lungs, chemical alteration of dust by acid or alkali should be minimized. A method which was mild to the minerals was treatment of the lung with $30 \% \mathrm{H}_{2} \mathrm{O}_{2}$. Fat was not destroyed by $\mathrm{H}_{2} \mathrm{O}_{2}$, but it can be removed by acetone before the lung tissue was decomposed by $\mathrm{H}_{2} \mathrm{O}_{2}$. Lung salt was extracted with suitable solvents. In this experiment, separation thechnique of dust from the lungs was essentially the same as that described in the previous paper. ${ }^{10}$

\section{Calibration}

For the diffractometer method of X-ray analysis a film of the standard mineral sample was formed on a glass slide by spreading with distilled water and 

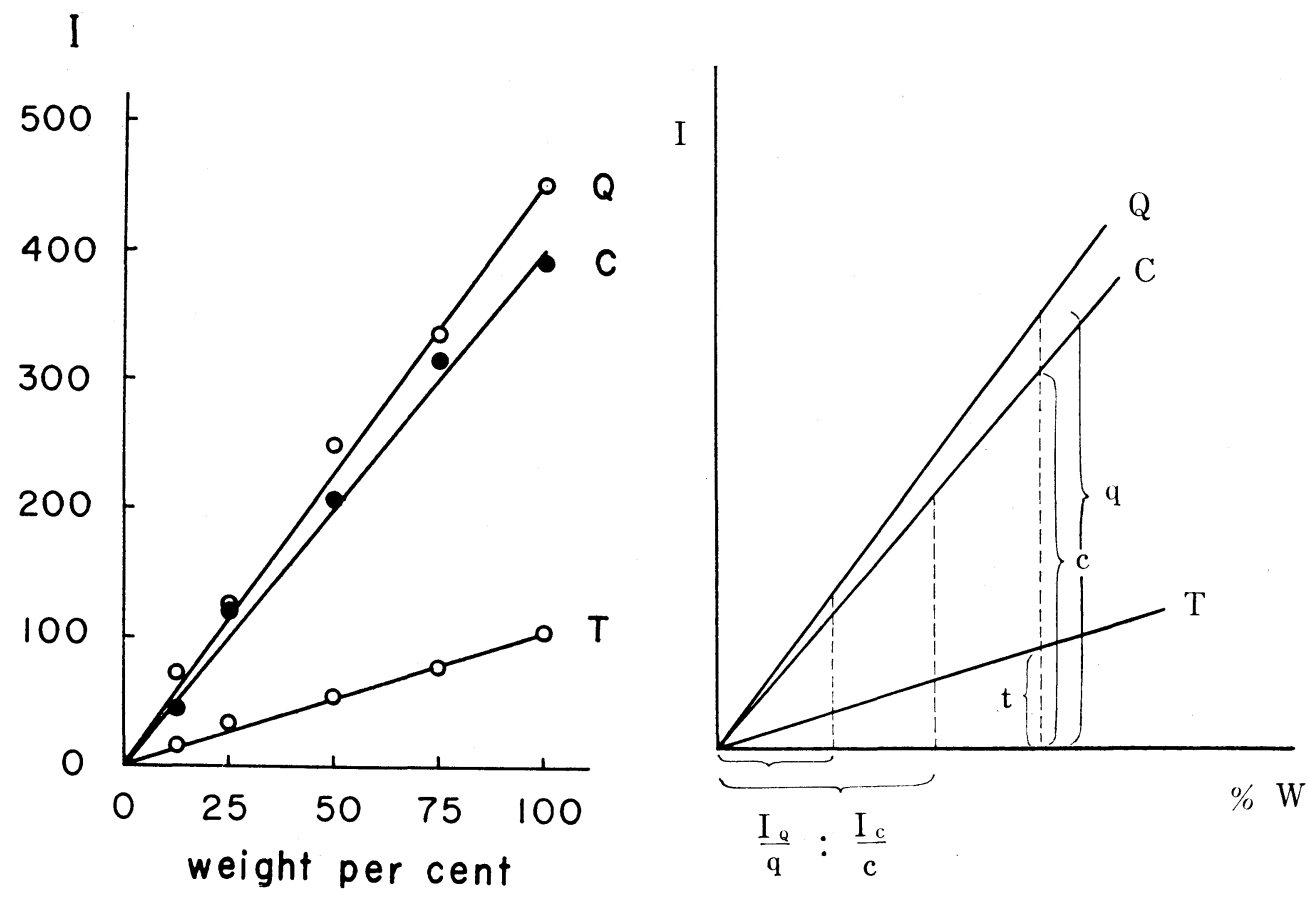

Fig.1-a (left). Calibration curves of Fig.1-b (right). Idealized expression of calibration quart $z$ contents $(\mathbf{Q})$, cristobalite contents (C) and tridymite curves. $\mathrm{I}_{Q}, \mathrm{I}_{\mathrm{C}}$ and $\mathrm{I}_{\mathrm{T}}$ : intensity of quartz $(3.34$ $\AA)$, cristobalite $(4.04 \AA$ ) and tridymite $(3.83 \AA$ ) contents $(\mathrm{T})$ by X-ray analysis. respectively. $\mathrm{W}$ : weight fraction of three minerals. $q, c$ and $t:$ gradient of each calibration curve.

drying in air. $0.4 \mathrm{~g}$ of various mixtures were spread over a glass slide in a fixed area of $2.0 \times 2.0 \mathrm{~cm}$.

The X-ray diffractometer scanning was set from $28^{\circ}$ to $19^{\circ}$ in the range of $2 \theta$ using filtered copper radiation, at a speed of $1 / 2^{\circ}$ per min, and time constant was 1 sec.

The standard series of mixture composed of various amounts of quartz, cristobalite and tridymite respectively were prepared for the calibration curves. X-ray diagrams of quartz, tridymite and cristobalite were recorded for the standards, for each mixture and also test samples. The $4.26 \AA$ quartz peak and the $4.31 \AA$ tridymite peak overlaped partly, and also the $4.09 \AA$ tridymite and $4.04 \AA$ cristobalite peak. Therefore, these peaks could not be used in quantitative estimation of such minerals.

The areas of the $3.83 \AA$ tridymite peak, the $4.04 \AA$ cristobalite peak, and the $3.34 \AA$ quartz peak were measured. The quartz content can be easily estimated from the intensity of the $3.34 \AA$ peak, since none of the other peaks interferes. The percentage of quart $z$ was directly proportional to the area of the $3.34 \AA$ quart $z$ peak, and the peak area is more proportional to the quart $z$ content than 


\section{SILICA MINERALS FROM REFRACTORY WORKERS' LUNGS}

peak intensity. For the determination of calibration curves of cristobalite and tridymite, each area of the $4.01 \AA$ cristobalite peak and the $3.83 \AA$ tridymite peak was plotted against their corresponding content in the mixture. Calibration curves representing these data are shown in Fig. 1. These curves were later used in estimation of unknown percentage of three polymorphs of the silica minerals in the dust from the lungs. The intensity of the X-ray diffraction pattern of each of three polymorphic silica minerals in a mixture should be directly proportional to its amount, since these minerals have the same mass absorption coefficent. As seen in Fig. 1-a, the obtained calibration curves for quartz, cristobalite and tridymite were almost straight. From Fig. 1, it could be deduced that the gradient ratio of calibration curves for quartz $(\mathbf{Q})$ and cristbalite $(\mathrm{C})$ was designated as $\mathrm{q}: \mathrm{c}=\tan \theta_{\mathrm{Q}}: \tan \theta_{\mathrm{C}}$, where $\tan \theta_{\mathrm{Q}}$ and $\tan \theta_{\mathrm{C}}$ represented the inclinations of the quartz and cristobalite lines to the horizontal axis. If the diffraction intensity of quart $z$ was equal to that of cristobalite, the amount ratio of quartz to cristobalite could be given as $1 / \mathrm{q}: 1 / \mathrm{c}=\mathrm{c}: \mathrm{q}$. The relative amounts of quartz and cristobalite in a sample, where minerals had the intensities $I_{Q}$ and $I_{C}$ respectively, could be expressed as $I_{Q} / q: I_{C} / c$. The relative amounts of quartz and cristobalite could be obtained from the intensity ratio of X-ray reflections of these two minerals and the gradient ratio $(q: c)$ of calibration curves. Also, the relative amount ratios of three kinds silica minerals could be easily calibrated on the basis of the intensity ratio by using the ratio $\mathrm{q}: \mathrm{c}: \mathrm{t}$, where $\mathrm{t}$ is gradient $\left(\tan \theta_{\mathrm{T}}\right)$ of the curve for tridymite $(T)$.

In this study, the gradient ratio of calibration lines of standard minerals was obtained as follows $; \tan \theta_{\mathrm{Q}}$ (quartz) $: \tan \theta_{\mathrm{C}}$ (cristobalite) $: \tan \theta_{\mathrm{T}}$ (tridymite) $=$ $4.5: 4.0: 1.0$. From the X-ray diffraction pattern of a specimen, peak area ratio of selected reflections of the constituent minerals is expressed as $I_{Q}$ (quartz): $I_{C}$ (cristobalite) $: \mathrm{I}_{\mathrm{T}}$ (tridymite). The relative amounts of these minerals can be obtained as $\mathrm{I}_{\mathrm{Q}} / 4.5: \mathrm{I}_{\mathrm{C}} / 4.0: \mathrm{I}_{\mathrm{T}} / 1.0$. Using this ratios, these three silica minerals as percentages of lung dusts are calculated from the quart $z$ amount obtained by the following infrared absorption analysis. In this procedure, it is not necessary to mix internal standard in test specimens.

\section{Infrared Absorption Analysis}

In order to determine the amount of quartz in a mixture of various minerals, infrared absorption spectra analysis was carried out. The technique was described in the previous paper.10)

\section{EXAMPle OF THE Application of This METhoD}

Following case is a practical procedure for the determination of silica minerals in lung dusts by the above mentioned method. The specimen No. 4 shown in the 


\section{H. HAYASHI AND K. OINUMA}

Table 1, collected from the right lung (8.35 gr. in dry weight) of a refractory worker, who was 37 years old, and worked for 12 years in refractory industry, was $42 \mathrm{mg}$. of dust.

\section{Quantitative Analysis of Lung Dusts}

1. Determination of relative amount ratios of three silica minerals.

Dust of $0.04 \mathrm{~g}$ in the specimen was spread over a glass slide in a fixed area of $2.0 \times 2.7 \mathrm{~cm}$, and was examined by X-ray. And then peak areas of diffractions at approximately $3.35 \AA$ by quartz, at $4.04 \AA$ by cristobalite and at $3.83 \AA$ by tridymite were measured. The measurement was repeated ten times, and the mean values of $I_{Q}, I_{C}$ and $I_{T}$ were obtained. In this specimen, $I_{Q}, I_{C}$ and $I_{T}$ were 216. $0,17.0$ and 10.5 respectively. The relative amount ratios of three silica minerals in this specimen were $216.0 / 4.5: 17.0 / 4.0: 10.5 / 1.0=48.00: 4.25: 10.5$.

2. Quartz as percentage.

The determination of quartz content was carried out easily by means of an infrared absorption spectroscopy. The absorption bant at $694 \mathrm{~cm}^{-1}$ on infrared spectrum is very useful in quantitative analysis of quartz, because the band at $694 \mathrm{~cm}^{-1}$ is not influenced by particle size, ${ }^{11,12)}$ and very sensitive to the small amount of quartz. Therefore, the infrared absorption band at about $694 \mathrm{~cm}^{-1}$ was used for determination of quartz. From this infrared absorption analysis, quart $z$ content in the specimen No. 4 was $52.0 \%$. If quartz content in the dust from the lungs

Table 1. Results of measurements of quartz, tridymite and cristobalite in lung dusts.

\begin{tabular}{|c|c|c|c|c|c|c|c|c|c|}
\hline & \multicolumn{2}{|c|}{ Specimen } & $\begin{array}{l}\text { Compositions } \\
\text { of dust from } \\
\text { lungs }\end{array}$ & $\begin{array}{l}\text { Dry weight } \\
\text { of lungs } \\
(\mathrm{g})\end{array}$ & $\begin{array}{l}\text { Amount of } \\
\text { dust from } \\
\text { lungs (mg) }\end{array}$ & $\begin{array}{l}\text { Relative amount ratio of } \\
\text { quartz, tridymite and } \\
\text { cristobalite in dust from } \\
\text { lungs } \\
\quad \text { Q : C : T }\end{array}$ & \multicolumn{3}{|c|}{$\begin{array}{l}\text { Mineral composition } \\
\text { of dust from lungs } \\
\text { (percentage) }\end{array}$} \\
\hline No. 4 & \multirow{2}{*}{$\begin{array}{l}\text { Workers } \\
\text { who worked } \\
\text { for } 12 \\
\text { years in } \\
\text { refractory } \\
\text { industry }\end{array}$} & $\begin{array}{l}\text { Upper } \\
\text { parts } \\
\text { of } \\
\text { right } \\
\text { lung }\end{array}$ & \multirow{4}{*}{$\begin{array}{l}\text { Quartz } \\
\text { tridymite } \\
\text { cristobalite } \\
\text { kaolin mineral } \\
\text { pyrophyllite }\end{array}$} & 8.35 & 42 & $48.00: 4.25: 10.5$ & 52 & 4.6 & 11.4 \\
\hline No. 5 & & \begin{tabular}{l|} 
Lower \\
parts \\
of \\
right \\
lung
\end{tabular} & & 9.95 & 74 & $36.96: 3.75: 5.0$ & 49 & 5.0 & 6.6 \\
\hline No. 12 & \multirow{2}{*}{$\begin{array}{l}\text { Workers } \\
\text { who worked } \\
\text { for } 11 \\
\text { years and } \\
6 \text { months } \\
\text { in } \\
\text { refractory } \\
\text { industry }\end{array}$} & $\begin{array}{l}\text { Right } \\
\text { lung }\end{array}$ & & 7.67 & 66 & $39.93: 3.00: 8.5$ & 50 & 3.8 & 10.6 \\
\hline No. 13 & & $\begin{array}{l}\text { Left } \\
\text { lung }\end{array}$ & & 9.28 & 22 & $34.10: 4.56: 12.0$ & 48 & 6.3 & 16.9 \\
\hline
\end{tabular}

Note. 1) Quartz contents are obtained by infrared absorption analysis.

2) Absolute amounts of tridymite and cristobalite is calibrated by multiplying the amount ratio of silica minerals. 


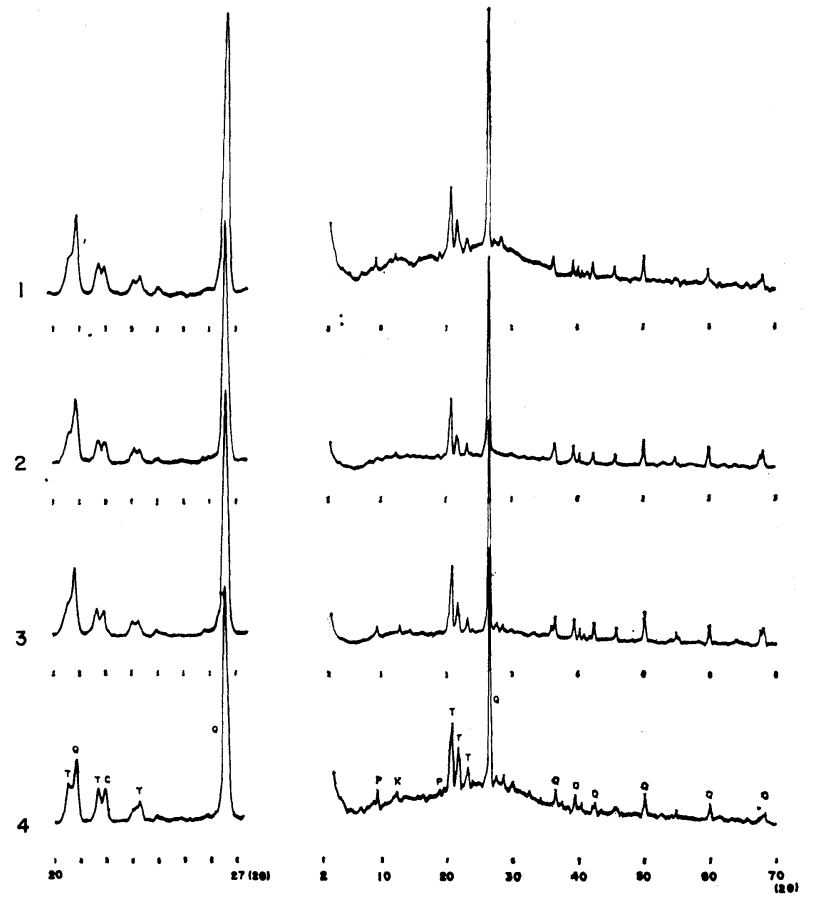

Fig. 2. X-ray powder patterns of the dusts from the pneumoconiotic lungs.

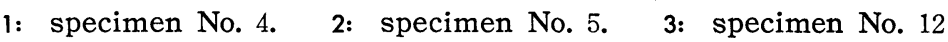
4: specimen No. 13.
$\mathrm{Q}$ : reflections of quartz. $T$ : reflections of tridymite.
C : reflections of cristobalite. $P$ : reflections of pyrophyllite.
$\mathrm{K}$ : reflection of kaolin mineral.

is determined, tridymite or cristobalite as percentages of total dust can be calculated from the relative amount ratios of silica minerals. In the specimen No. 4, the relative amounts of three silica minerals were obtained as $I_{Q} / q: I_{C} / c: I_{T} / t$ $=216.0 / 4.5: 17.0 / 4.0: 10.5 / 1.0=48.00: 4.25: 10.50 . \quad \mathrm{I}_{Q} / \mathrm{q}$ corresponds to $52.0 \%$ in this specimen. Therefore, cristobalite or tridymite contents can be calibrated from this value of quartz content. Cristobalite was $4.60 \%$ and tridymite was $11.37 \%$.

By the same procedure, the lungs of two refractory workers were analyzed. Data are shown in Table 1.

\section{Qualitative Analysis of Lung Dusts of Refractory Workers}

Mineral dusts in the pneumoconiotic lungs of a refractory worker (No. 4) were also determined qualitatively by the technique which was reported in the previous paper. ${ }^{10)} \quad$ As shown in Fig. 2, a small amount of clay minerals were confirmed besides silica minerals. Identification of these clay minerals was difficult, although the weak reflections of $10 \AA$ and $7 \AA$ were confirmed in the specimens. For more 


\section{H. HAYASHI AND K. OINUMA}

precise identification of clay minerals, samples were treated by ethylene glycol and heat. By these treatments, the clay minerals were proved to be pyrophyllite and kaolin minerals.

The infrared spectrum of this specimen was shown in Fig. 3. The infrared
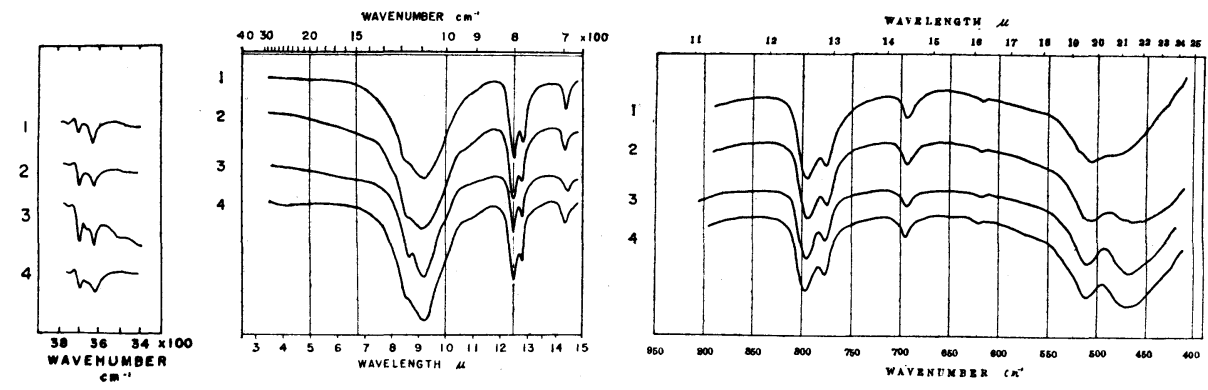

Fig. 3. Infrared spectra of the dusts from the pneumoconiotic lungs

1: specimen No. 4. 2: specimen No. 5. 3: specimen No. 12 4: specimen No. 13.

absorption spectrum of the lung dust showed a triple band near $3700, \mathrm{~cm}^{-1}$, such as 3670,3660 and $3625 \mathrm{~cm}^{-1}$, which was characteristic band of kaolin minerals in the $\mathrm{OH}$ region from 3800 to $3200 \mathrm{~cm}^{-1}$, and showed a very strong band between 1100 and $1080 \mathrm{~cm}^{-1}$ and bands at 800,780,694,620,560, and $480 \mathrm{~cm}^{-1} \quad$ The band at $620 \mathrm{~cm}^{-1}$ is one of the characteristic bands of tridymite. The band at $694 \mathrm{~cm}^{-1}$ is due to quartz.

By these analysis, dusts from the lungs of a refractory worker (No. 4) were proved to be composed of quartz, tridymite, cristobalite, kaolin minerals and pyrophyllite.

The dusts from the lungs of refractory workers were analyzed by same procedure. Data of X-ray and infrared analysis were shown in Fig. 2 and 3.

\section{DISCUSSION}

Loeckell et al. (1961) studied mineral dusts in chamote lung. ${ }^{13)}$ According to their report, despite the fact that airborne dusts were consisted of tridymite $(35 \%)$, quartz (less than $5 \%$ ) and mullite (less than $3 \%$ ) in chamote industry where patient had worked for about 5 years, tridymite could not be found in lung dust isolated by formamide. As Thomas (1956) and Loeckell et al. (1961) recognized, ${ }^{13,14)}$ tridymite is dissolved by treatment of the lungs with water-free formamide. The separation method of the dust from the lungs must be selected considering the mineral components of lung dust.

Buerger (1954) defined that tridymite was a complex-stuffed compound in which the $\mathrm{Si}^{4+}$ cation was easily replaced by $\mathrm{Al}^{3+}$ in tetrahedral $\left(\mathrm{RO}_{4}\right)$ co-ordinated groups. $\left.{ }^{15}\right)$ $\mathrm{K}_{2} \mathrm{O}, \mathrm{Na}_{2} \mathrm{O}, \mathrm{CaO}$ and $\mathrm{Al}_{2} \mathrm{O}_{3}$ are generally seen in tridymite crystals, and sometimes thier amounts reach $10 \%$. The differential thermal analysis curves of various 


\section{SILICA MINERALS FROM REFRACTORY WORKERS' LUNGS}

tridymites have a rather complex character, and many of them show two inversion effects. The grade of disorder is different according to samples. The X-ray diagrams show variabilities in various tridymites which are classified as tridymite generally. In cristobalites of various degrees of crystallinity, endothermic peaks between $230^{\circ} \mathrm{C}$ and $260^{\circ} \mathrm{C}$ shift from lower temperature to higher temperature with increasing structural disorders. The X-ray diagrams of cristobalite show an increasing diffuseness of lines and the reduction of their intensities with the defects of structure. Therefore, the determination of tridymite is not so easily, because the X-ray patterns of tridymite and cristobalite do not match any patterns reported in the literatures in many cases. ${ }^{16 \sim 20)}$ It was found, however, that the patterns of the tridymite and cristobalite prepared for this study very closely resembled the pattern of the dust from the lungs.

The procedure described in this paper is a rapid method of estimating approximately relative amounts of silica minerals in a very small amount of dust from the lungs. This X-ray procedure can omit the process of mixing test specimens and internal standard, and avoid decrease in reflection intensity of silica minerals, because the specimen do not contain internal standard. Furthermore, there is another advatage, that is, after this X-ray analysis the specimen can be used for some other methods, such as infrared absorption analysis and differential thermal analysis.

From the application of this method to the lungs of refractory workers, it was proved that this procedure was superior in qualitative and quantitative determination of a small amount of the lung dusts to other methods, as it can produce a marked effect from a small amount of specimen.

\section{ACKNOWLEDGEMENTS}

The writers are indebted to Dr. H. Sakabe for his valuable suggestions rendered during the course of this work. They express their thanks to Prof. A. Kajita for furnishing them with the lung tissues. Their thanks are also due to Prof. S. Kunitomi and Prof. T. Adachi for continuous encuragement. They are indebted to Dr. K. Oouti for permission of the use of infrared spectrometer.

\section{REFERENCES}

1) Fenner, C. N. (1913). Am. J. Sci. (4th Series) 36, 331.

2) Flörke, O. W. (1955). Ber. Deut. Keram. Ges. 32, 369.

3) Holmquist, S. B. (1958). Z. Krist., 111, 71.

4) Holmquist, S. B. (1961). J. Am. Ceram. Soc., 44, 82.

5) Mason, B. (1953). Am. Mineralogist, 38, 866.

6) Chaklader, A. C. D. and Roberts, A. L. (1961). I. Am. Ceram. Soc., 44, 35.

7) Chaklader, A. C. D. and Roberts, A. L. (1958). Trans. Brit. Ceram. Soc., 57, 1115.

8) Chaklader, A. C. D. (1963). J. Am. Ceram. Soc., 46, 66. 


\section{H. HAYASHI AND K. OINUMA}

9) Cartwright, I. and Nagelschmidt, G. (1961). Inhaled Particles and Vapors (Edited by Davies, C. N.), p. 445. Pergamon Press, Oxford.

10) Hayashi, H. (1963). Ind. Health, 1, 37.

11) Tuddenham, W. M. and Lyon, R. J. P. (1960). Anal. Chem., 32, 1630.

12) Soda. R. (1960). Bull. Nat. Inst. Ind. Health, 4, 29.

13) Loeckell, H., Knorr, G., Einbrodt, H. J. and Fitzek, J. (1961). Beitr. Silikose-Forsch. 70, 1.

14) Thomas, K. (1956). Beitr. Silikose-Forsch. I, "Grundfragen aus der Silikose-Forschung", 1, 57.

15) Buerger, M. J. (1954). Am. Mineralogist, 39, 600.

16) A. S. T. M. Diffraction Data File. No. 1-0378, No. 2-0242, No. 3-0227.

17) Agamawi, Y. M. and White, J. (1953). Trans. Brit. Ceram. Soc. 52, 271.

18) Hill, V. G. and Roy, R. (1958). Trans Brit. Ceram. Soc., 57, 496.

19) Sandford, F. and Sandrén, Å. (1963). Trans. Chalmærs Univ. Technol. Gothenburg, Nr. 281, 3.

20) Sato. M. (1962). Mineral. J. (Tokyo), 3, 296.

21) Sato, M. (1964). Mineral. J. (Tokyo), 4, $115 \& 131$. 